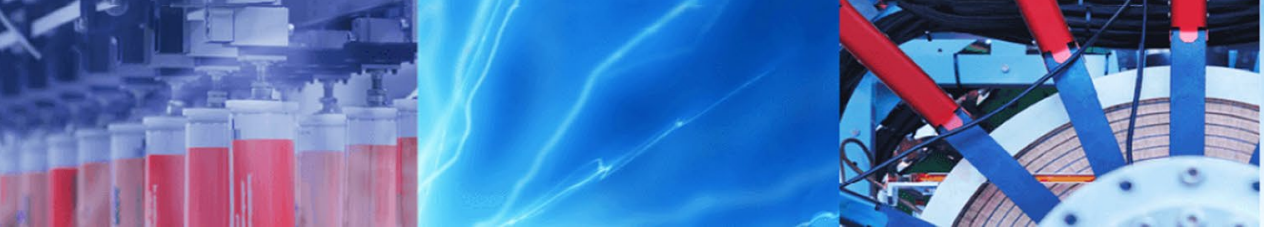

Research Article

\title{
Degradation of olive mill wastewater by different methods and antioxidant activity of olive mill wastewater extraction
}

\author{
Ezgi Evci ${ }^{1}$ Ö̈zgür Yılmaz ${ }^{1}$ (D) Esen Yıldız Bekfelavi ${ }^{1} \cdot$ Nermin Şimşek Kuş ${ }^{1}$ (D)
}

(c) Springer Nature Switzerland AG 2019

\begin{abstract}
Olive wastewater (OMW) is an important environmental problem due to the high phenol level and contains organic substances such as sugars, organic acids, polyalcohols, pectins, colloids, tannins, and lipids. Removing OMW is difficult because of the high concentrations of chemical oxygen demand (COD), biochemical oxygen demand, and phenolic compounds. In this study, we concentrated on the degradation of OMW to solve this problem. The degradation of OMW at high pressure and temperature (with $\mathrm{H}_{2} \mathrm{O}_{2}$ and without $\mathrm{H}_{2} \mathrm{O}_{2}$ ), at room temperature and atmospheric pressure with $\mathrm{H}_{2} \mathrm{O}_{2}$, at room temperature and atmospheric pressure with $\mathrm{O}_{3}$, and with ultrasound-assisted ozonation, was investigated by means of COD, phenolic compounds, and sulfur analyses. The results showed that the method of high pressure and temperature with $\mathrm{H}_{2} \mathrm{O}_{2}$ was the most successful. $\mathrm{H}_{2} \mathrm{O}_{2}$ at high pressure $\left(\mathrm{O}_{2}\right)$ and temperature removed $89.2 \%$ of COD, $91.5 \%$ of phenolic compounds, and color of OMW. With this result, we showed that the use of $\mathrm{O}_{2}$ atmosphere instead of $\mathrm{N}_{2}$ is important for degradation and also especially for color removing. In addition, the antioxidant property of OMW was also examined. Fourier-transform infrared spectroscopy of the extracts revealed vibration bands corresponding to acid, alcohol, and ketone groups. The results showed that high pressure and temperature treatment is very effective for removing phenolic compounds from olive oil wastewater. In addition, 2,2-diphenyl-1-picrylhydrazyl (DPPH) scavenging potential of OMW in the Çukurova area of Turkey was studied and the $\mathrm{IC}_{50}$ value of $\mathrm{OMW}$ was determined to be $118 \mu \mathrm{g} / \mathrm{mL}$.
\end{abstract}

Keywords Olive mill wastewater · Subcritical water · Chemical oxygen demand · Degradation · Mersin · Antioxidant activity

\section{Introduction}

Olive mill wastewater occurs during the production of olive oil by olive oil factories. The olive industry is very important in Mediterranean countries, particularly Greece, Syria, Spain, Tunisia, Italy, and Turkey. OMW is a considerable source of pollution because of its high phytotoxicity. The management of OMW has been widely researched and some comprehensive and detailed reviews focusing mainly on management have been published recently $[6$, $9,10,22,25]$. Adhoum and Monser [4] studied decolorization and removal of phenolic compounds from OMW by electrocoagulation. Jarboui et al. [15] studied OMW evaporation pond management in five serial evaporation open-air multiponds of 50 ha located in Sfax (Tunisia). Nassar et al. [21] investigated the effectiveness of magnetic iron oxide nanoparticles for removal of large organic contaminants from OMW waters by flocculation. Beltran-Heredia et al. [7] studied the degradation of OMW by means of two chemical oxidation processes (Fenton's reagent and ozonation) with aerobic microorganisms. In addition, some filtration methods of OMW $[1,3]$ can be found in the literature, but these methods generally reduce the COD instead of completely exhausted. The extraction of olive oil produces waste in large quantities with environmental impact due to its high phytotoxicity. For this reason, there

Özgür Yılmaz, yilmazozgur@mersin.edu.tr; $₫$ Nermin Şimşek Kuş, simner@mersin.edu.tr| ${ }^{1}$ Department of Chemistry, Mersin University, 33343 Mersin, Turkey.

SN Applied Sciences (2019) 1:1206 | https://doi.org/10.1007/s42452-019-1210-0

Received: 23 May 2019 / Accepted: 31 August 2019 / Published online: 12 September 2019

SN Applied Sciences

A SPRINGER NATURE journal 
is a need for guidelines to manage these wastes with technologies that reduce the environmental impact as much as possible and lead to sustainable use of resources.

The aim of this work was to study the effect of different methods (high pressure and temperature (with $\mathrm{H}_{2} \mathrm{O}_{2}$ and without $\mathrm{H}_{2} \mathrm{O}_{2}$ ), at room temperature and atmospheric pressure with $\mathrm{H}_{2} \mathrm{O}_{2}$, at room temperature and atmospheric pressure with $\mathrm{O}_{3}$, and with ultrasound-assisted ozonation) for oxidation of OMW, regarding the effect of various operating conditions (initial chemical oxygen demand (COD), $\mathrm{pH}$, sulfur, phenol, and density) on the removal of color, phenolic, and organic compounds. The results of these experiments showed that the high pressure with $\mathrm{H}_{2} \mathrm{O}_{2}$ is a good choice for degradation, because subcritical water oxidation method is an environmentally friendly and effective with short treatment time that is important for cost [30] and the $\mathrm{O}_{2}$ has an important effect for degradation and color removing. In addition, we investigated the antioxidant properties of OMW in order to evaluate it instead of degradation. The sample used in our experiments was taken from the OMW pools in Mersin (Turkey).

\section{Experimental section}

\subsection{Chemicals and reagents}

Hach Cat. 2106869 PK/100 CyaniVer 3 cyanide reagent powder Pifiows for $10 \mathrm{~mL}$ sample, Hach Cat. 2106969 $\mathrm{PK} / 100$ CyaniVer 4 cyanide reagent for $10 \mathrm{~mL}$ sample, Hach Permachem reagents Cat. 2107069 PK/100 CyaniVer 5 cyanide reagent for $10 \mathrm{~mL}$ sample, Hach Cat 42449 buffer Solution Hardness 1 Solution pH $10.1 \pm$, Hach Permachem reagents Cat. 183699 phenol 2 reagent, Hach Permachem reagents Cat. 87299 phenol reagent, LCK 314 15-150 mg/L $\mathrm{O}_{2}$ CSB, COD, DCO LCK 314 were the chemicals used for analytical purposes. $\mathrm{H}_{2} \mathrm{O}_{2}$ was taken from Sigma-Aldrich as a $35 \%$ solution.

\section{$2.20 \mathrm{OMW}$}

OMW was obtained from the olive oil factory in Mersin (Turkey). The fresh OMW sample was initially completely cloudy and homogeneous. After $24 \mathrm{~h}$, the sample was completely stationary and divided into two net layers at the macro level. For this reason, the sedimentation time was required to obtain a very clear supernatant is $24 \mathrm{~h}$. The contents are shown in Table 1. The high pressure and temperature reactions were carried out in a stainless steel
Table 1 Characterization of the OMW used in the experiments

\begin{tabular}{ll}
\hline Parameter & Range \\
\hline Total COD & $83,000 \mathrm{mg} / \mathrm{L}$ \\
Total TOC & $29,000 \mathrm{mg} / \mathrm{L}$ \\
Phenolics & $4.8 \mathrm{~g} / \mathrm{L}$ \\
Sulfur & $31 \mathrm{mg} / \mathrm{L}$ \\
$\mathrm{pH}$ & 4.7 \\
Density & $1.0026 \mathrm{mg} / \mathrm{L}$ \\
Color $^{\mathrm{a}}$ & $139 \mathrm{~cm}^{-1}$ \\
Oil and grace $^{-}$ & $7.8 \mathrm{~g} / \mathrm{L}$ \\
\hline
\end{tabular}

${ }^{\mathrm{a}}$ Absorbance at $400 \mathrm{~nm}$

reactor [17]. The experiments with $\mathrm{O}_{3}$ and $\mathrm{H}_{2} \mathrm{O}_{2}$ were also performed at atmospheric pressure.

\subsection{Experimental procedure}

The experiments were carried out under seven different sets of conditions. Four experiments in high pressure and temperature were performed in the reactor. An experiment was conducted at atmospheric pressure with $3 \mathrm{~mL}$ of $\mathrm{H}_{2} \mathrm{O}_{2}$ at reflux temperature in a flask for $3 \mathrm{~h}$. An experiment was realized at atmospheric pressure with $\mathrm{O}_{3}$ at reflux temperature for $3 \mathrm{~h}$. An experiment was effected in atmospheric pressure in the sonic-assisted reaction with $\mathrm{O}_{3}$ at $100^{\circ} \mathrm{C}$ for $3 \mathrm{~h}$.

\subsection{Degradation of OMW at high temperature and pressure}

The reactor has $100-\mathrm{mL}$ capacity with a thermostatically controlled magnetic stirrer. In condition 1, the experiment was carried out at 40 bar oxygen pressure at $150^{\circ} \mathrm{C}$ for $3 \mathrm{~h}$. In condition 2, the experiment was carried out at 40 bar oxygen pressure with $1 \mathrm{~mL}$ of $\mathrm{H}_{2} \mathrm{O}_{2}$ at $150{ }^{\circ} \mathrm{C}$ for $3 \mathrm{~h}$. In condition 3 , the experiment was carried out at 40 bar oxygen pressure with $3 \mathrm{~mL}$ of $\mathrm{H}_{2} \mathrm{O}_{2}$ at $150{ }^{\circ} \mathrm{C}$ for $3 \mathrm{~h}$. In condition 4, the experiment was carried out at 40 bar nitrogen pressure with $3 \mathrm{~mL}$ of $\mathrm{H}_{2} \mathrm{O}_{2}$ at $150{ }^{\circ} \mathrm{C}$ for 3 h. $50 \mathrm{~mL} \mathrm{OMW}$ was put into the reactor and mixed. The reactor was then shut down and turned off; gas was evacuated, and the temperature was raised to $150^{\circ} \mathrm{C}$. After the temperature reached $150^{\circ} \mathrm{C}$, the process was continued for $3 \mathrm{~h}$. In addition, $\mathrm{H}_{2} \mathrm{O}_{2}$ was added to the medium in the two experiments. When the experiments were completed, analyses (COD, phenol, sulfur, density, and $\mathrm{pH}$ ) of the OMW were performed. 


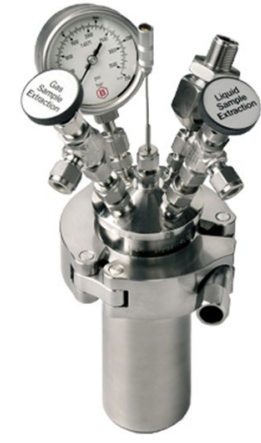

\subsection{With $\mathrm{O}_{3}$ under sonochemical conditions}

OMW was put into a 100-mL three-necked flask equipped with a condenser and subjected to ultrasonic irradiation at reflux temperature for the appropriate time for $3 \mathrm{~h}$. After the reaction, analyses (COD, phenol, sulfur, density, and $\mathrm{pH}$ ) of the OMW were performed. A Bandelin Soporex RK $255 \mathrm{H}$ model was used for ultrasonic reactions.

\subsection{With $\mathrm{O}_{3}$}

A $100-\mathrm{mL}$ three-necked flask was equipped with a condenser, and $\mathrm{O}_{3}$ inlet was charged with OWM. The suspension was stirred under $\mathrm{O}_{3}$ at room temperature for $3 \mathrm{~h} . \mathrm{O}_{3}$ was given continuous flow during the experiment. After the reaction, analyses (COD, phenol, sulfur, density, and $\mathrm{pH}$ ) of the OMW were performed.

\subsection{Analytical methods}

The OMW used in this investigation was characterized by measuring $\mathrm{pH}$, density, total phenols, $\mathrm{COD}$, and sulfur concentration. Various parameters were measured during the experiments. The COD was determined by the reactor digestion method for COD, phenol, and sulfur range of 0-1500 mg/L using a HACH LANGEDR 5000 analyzer. pH was measured with a Mettler Toledo mp225. Infrared spectra were recorded with a Perkin Elmer Win First ${ }^{\circledast}$ Satellite and UV-Vis spectrophotometer from Shimadzu was used for antioxidant measurements. Finally, all the experiments were performed at least twice and the analytical methods were applied at least in triplicate.

\subsection{COD measurement}

Firstly, $1 \mathrm{~mL}$ of sample diluted 100 times for COD measurement. Then, $2 \mathrm{~mL}$ of sample from diluted solution was placed in the COD tube and it was heated at $150^{\circ} \mathrm{C}$ for $2 \mathrm{~h}$.
When the contents of the tube reached room temperature, the measurement was performed.

\subsection{Sulfur content}

Distilled water and OMW were put into the spectrophotometer cuvettes and the wavelength was adjusted to $665 \mathrm{~nm}$. While the cuvettes were being shaken, $0.5 \mathrm{~mL}$ of sulfide 1 reagent was added. Then, during further shaking of the tubes, $0.5 \mathrm{~mL}$ of sulfide 2 reagent material was introduced and pink color was formed. First the distilled water and then the sample was read and the values were recorded.

\subsection{Phenol content}

Distilled water and OWM were placed in different separation funnels. Then, $5 \mathrm{~mL}$ of hardness 1 buffer was added to both separation funnels. The phenol reagent powder pillow was added to the separation funnel, which was then shaken. Next, phenol 2 reagent powder pillow was added followed by rinsing. Finally, $30 \mathrm{~mL}$ of chloroform was added to the two separation funnels and they were shaken thoroughly. After phase separation, the chloroform phase was read at $460 \mathrm{~nm}$ on the spectrophotometer. All the analyses were done in duplicate. Removal yields were assessed as phenolic loss index (PLI) [20] and sulfur loss index (SLI) using the following equations:

$$
\begin{gathered}
\mathrm{PLI}(\%)=\left[\left(\mathrm{Ph}_{\mathrm{ni}}-\mathrm{Ph}_{\mathrm{nf}}\right) /\left(\mathrm{Ph}_{\mathrm{ni}}\right)\right] \times 100 \\
\left(\mathrm{Ph}_{\mathrm{ni}}=\right.\text { initial phenolics concentration; } \\
\left.\mathrm{Ph}_{\mathrm{nf}}=\text { final phenolics concentration }\right)
\end{gathered}
$$

$$
\begin{aligned}
& \mathrm{SLI}(\%)=\left[\left(S_{\mathrm{ni}}-S_{\mathrm{nf}}\right) /\left(S_{\mathrm{ni}}\right)\right] \times 100 \\
& \left(S_{\mathrm{ni}}=\text { initial sulfur concentration; } S_{\mathrm{nf}}=\text { final sulfur concentration }\right)
\end{aligned}
$$

\subsection{Antioxidant activity of OWM extract}

Antioxidant activity was measured using the 2,2-diphenyl-1-picrylhydrazyl (DPPH) radical scavenging test. The antioxidant activity was performed using the DPPH radical scavenging assay. Butylated hydroxytoluene $(\mathrm{BHT})$ and butylated hydroxyanisole $(\mathrm{BHA})$ were used as reference test materials. Firstly, different concentrations $(6.75-1600 \mu \mathrm{g} / \mathrm{mL})$ of reference test materials and samples were prepared in EtOH. Then, $1 \mathrm{~mL}$ of each sample was added to $1 \mathrm{~mL}$ of $1 \times 10^{-4} \mathrm{mM}$ DPPH solution that prepared as newly, and they were incubated in dark for half an hour at room temperature. Then, the absorbance for each sample was measured at $517 \mathrm{~nm}$. The percentage of scavenging activity in the experiment 
was calculated using the formula given below. The $\mathrm{IC}_{50}$ (inhibitory concentration) is the concentration required to clear 50\% DPPH free radicals (Eq. 3) [13].

$\%$ Scavenging $=\left(A_{\mathrm{o}}-A_{\mathrm{s}} / A_{\mathrm{o}}\right) \cdot 100$

$\left(A_{\mathrm{o}}=\right.$ absorbance of the control;

$A_{\mathrm{s}}=$ absorbance of the sample at $517 \mathrm{~nm}$ )

\section{Results and discussion}

In our study, the degradation of OMW in subcritical water (with $\mathrm{H}_{2} \mathrm{O}_{2}$ and without $\mathrm{H}_{2} \mathrm{O}_{2}$ ), at room temperature and atmospheric pressure with $\mathrm{H}_{2} \mathrm{O}_{2}$, at room temperature and atmospheric pressure with $\mathrm{O}_{3}$, and with ultrasound-assisted ozonation, was investigated by means of COD, phenolic compounds, and sulfur analyses. Table 2 shows the properties of the supernatant before and after oxidation. As seen, the specimen's properties after oxidation changed drastically. In particular, a large decrease in COD was observed at high pressure $\left(\mathrm{O}_{2}\right)$ and temperature in the presence of $\mathrm{H}_{2} \mathrm{O}_{2}$. Again, the $\mathrm{pH}$ of the solution is slightly acidic, which may depend on the presence of high concentrations of phenolic compounds and carboxylic acids, which are classified as weak acids.

When we look at the details in this works, the reduction in COD, SLI, and PLI values fell from $43.6 \%, 99.7 \%$, and $20.8 \%$, respectively, when an ultrasonic bath was not used with ozone (Table 2/entry 2), but when using an ultrasonic bath with ozone, these values changed as $50.8 \%, 99.7 \%$, and $25.0 \%$, respectively (Table 2 /entry 3). Beltran-Heredia et al. [8] studied degradation of OMW by ozonation in chemical batch reactor, and they obtained the COD reduction between 42 and $55 \%$. It is seen that this result is approximately the same as the result we obtained in our ozonation study. These results showed that the ultrasonic bath significantly increases the removal of OMW and can be used as an alternative method.

When only $\mathrm{H}_{2} \mathrm{O}_{2}$ was used in oxidation, the reduction in COD, SLI, and PLI values was $80.6 \%, 97.1 \%$, and $14.6 \%$, respectively (Table 2 /entry 4 ). Several important organic reactions in subcritical water are described in the literature [17]. In particular, oxidation reactions were described using molecular oxygen as an oxidant. We also used subcritical water oxidation in the oxidation reactions. OMW was treated by molecular $\mathrm{O}_{2}$ at high pressure and temperature water $\left(40\right.$ bar $\mathrm{O}_{2}$, $\left.150{ }^{\circ} \mathrm{C}\right)$. COD and the levels of sulfur and phenol are all showed decreases, which, after $3 \mathrm{~h}$ treatment, and reached $28 \%, 99.2 \%$, and $91.0 \%$, respectively (Table $2 /$ entry 5). There was no significant change in $\mathrm{pH}$. When the reaction ( 40 bar $\mathrm{O}_{2}, 150^{\circ} \mathrm{C}$ ) was performed in the presence of $1 \mathrm{~mL} \mathrm{H} \mathrm{O}_{2}, \mathrm{COD}$ and the levels of sulfur and phenol decreased by $78.4 \%, 99.5 \%$, and $90.2 \%$, respectively (Table 2 /entry 6 ). The best COD, SLI, and $\mathrm{PLI}$ results were observed in subcritical conditions in the presence of $3 \mathrm{~mL}$ of $\mathrm{H}_{2} \mathrm{O}_{2}$ at $89.2 \%, 99.8 \%$, and $91.5 \%$, respectively (Table 2/entry 7 ). Yabalak et al. [29] studied degradation of OMW using subcritical water conditions, and they obtained 96\% COD removal in their best condition, but they did not mention color or smell removing in their best condition. Also, they have used $\mathrm{N}_{2}$ gas for degradation process. In our works, we investigated effect of different gases $\left(\mathrm{N}_{2}\right.$ and $\left.\mathrm{O}_{2}\right)$ for degradation. For this purpose, we set up the control reaction in $\mathrm{N}_{2}$ atmosphere instead of $\mathrm{O}_{2}$ for understanding the effect of $\mathrm{O}_{2}$ (Table 2/entry 8 ). Also, we set up reactions under the low temperature in $\mathrm{O}_{2}$ atmosphere (40 bar $\mathrm{O}_{2}, 50{ }^{\circ} \mathrm{C}$, and 40 bar $\mathrm{O}_{2}, 100^{\circ} \mathrm{C}$ ) for understanding the effect of high temperature. According to the result of these control and optimization reactions, we could not obtain any good COD, color, and smell removing. These results showed that the subcritical water oxidation is an

Table 2 Experiments and analysis results

\begin{tabular}{|c|c|c|c|c|c|c|c|c|c|}
\hline Rank & Conditions & $\mathrm{COD}^{\mathrm{a}}(\mathrm{mg} / \mathrm{L})$ & $\begin{array}{l}\text { COD\% } \\
\text { reduc- } \\
\text { tion }\end{array}$ & Sulfur (mg/L) & SLI (\%) & Phenol (g/L) & PLI (\%) & Density(mg/L) & $\mathrm{pH}$ \\
\hline 1 & Untreated olive mill wastewater & 830 & - & 31 & - & 4.8 & - & 1.0026 & 4.7 \\
\hline 2 & $\mathrm{O}_{3}, 100^{\circ} \mathrm{C}, 6 \mathrm{~h}$ & 470 & 43.6 & 0.080 & 99.7 & 3.8 & 20.8 & 1.0044 & 4.3 \\
\hline 3 & $\mathrm{O}_{3}, 100^{\circ} \mathrm{C}, 6 \mathrm{~h}$ sonication & 410 & 50.8 & 0.082 & 99.7 & 3.6 & 25.0 & 1.0081 & 2.8 \\
\hline 4 & $3 \mathrm{~mL} \mathrm{H}_{2} \mathrm{O}_{2} 100^{\circ} \mathrm{C}, 6 \mathrm{~h}$ & 161.5 & 80.6 & 0.89 & 97.1 & 4.1 & 14.6 & 1.0068 & 3 \\
\hline 5 & 40 bar $\mathrm{O}_{2} 150^{\circ} \mathrm{C}, 3 \mathrm{~h}$ & 600 & 28 & 0.242 & 99.2 & 0.43 & 91.0 & 1.0019 & 4.8 \\
\hline 6 & 40 bar $\mathrm{O}_{2} 150^{\circ} \mathrm{C}, 3 \mathrm{~h} 1 \mathrm{~mL} \mathrm{H}_{2} \mathrm{O}_{2}$ & 180 & 78.4 & 0.168 & 99.5 & 0.47 & 90.2 & 1.0018 & 4.7 \\
\hline 7 & 40 bar $\mathrm{O}_{2} 150^{\circ} \mathrm{C}, 3 \mathrm{~h} 3 \mathrm{~mL} \mathrm{H}_{2} \mathrm{O}_{2}$ & 90 & 89.2 & 0.072 & 99.8 & 0.41 & 91.5 & 1.0014 & 4.8 \\
\hline 8 & 40 bar $\mathrm{N}_{2} 150^{\circ} \mathrm{C}, 3 \mathrm{~h} 3 \mathrm{~mL} \mathrm{H}_{2} \mathrm{O}_{2}$ & 474 & 42.9 & & 98.3 & 2.6 & & 1.0036 & 4.4 \\
\hline
\end{tabular}

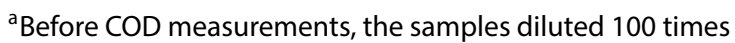


effective method for degradation of OMW, and when, the $\mathrm{H}_{2} \mathrm{O}_{2}$ was used as co-oxidant with $\mathrm{O}_{2}$ atmosphere, the degradation of OMW increased drastically. Also, using $\mathrm{O}_{2}$ atmosphere instead of $\mathrm{N}_{2}$ is very important for color and smell removing (Fig. 1).

The $\mathrm{pH}$ of the medium was decreased in the $3 \mathrm{rd}$ and 4th experiment conditions. No significant change in OMW concentrations was observed.

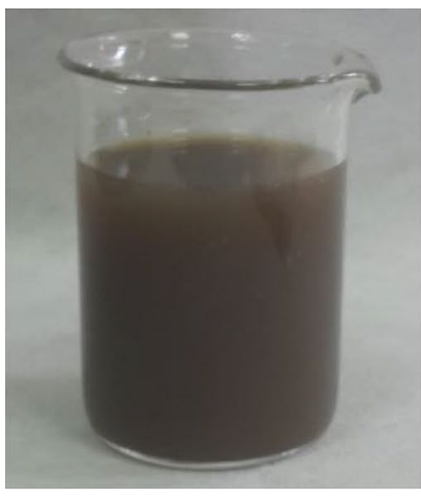

(a)

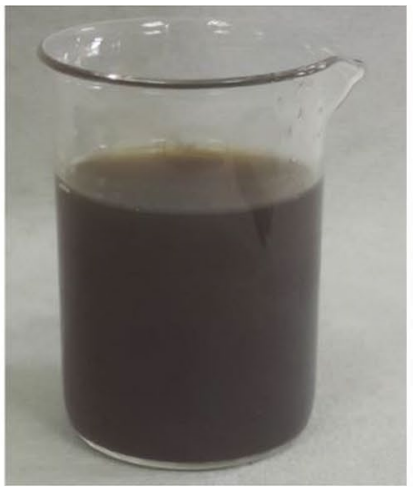

(b)

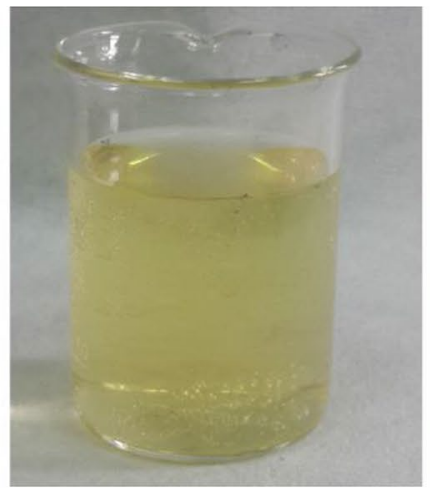

(c)

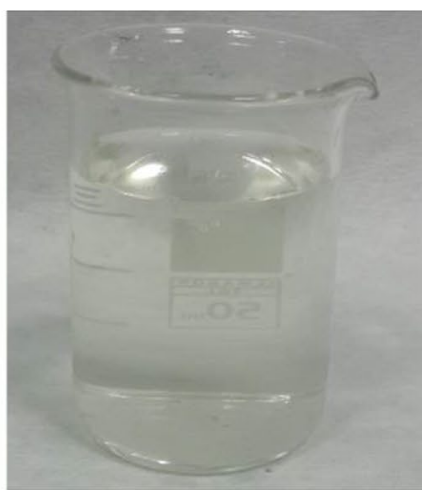

(d)

Fig. 1 Picture of the solution before and after degradation a OWM, b after degradation with condition in Table 2/entry 8, c after degradation with condition in Table 2/entry 6, and $\mathbf{d}$ after degradation with condition in Table 2/entry 7

Table 3 Absorbance bands from the FTIR spectra in the extract made with hexane of OMW

\begin{tabular}{ll}
\hline Wavenumber & Assignments \\
\hline $2954-2848 \mathrm{~cm}^{-1}$ & $\begin{array}{c}\mathrm{C}-\mathrm{H} \text { stretching in aliphatic structures (fatty acids, waxes, and other long- } \\
\text { chain structures) } \\
\mathrm{C}=\mathrm{O} \text { stretching in carboxyls, acids, and ketones }\end{array}$ \\
$1699 \mathrm{~cm}^{-1}$ & $\mathrm{C}-\mathrm{H}$ stretching in aliphatic structures \\
$1463-1431 \mathrm{~cm}^{-1}$ & $\mathrm{C}-\mathrm{H}$ deformation of $\mathrm{CH}_{2}$ and $\mathrm{CH}_{3}$ groups, $\mathrm{COO}^{-}$antisymmetric stretching \\
$1347 \mathrm{~cm}^{-1}$ & $\mathrm{C}-\mathrm{O}$ of ethers on an aromatic ring and the $\mathrm{N}-\mathrm{H}$ of amides II \\
$1347-934 \mathrm{~cm}^{-1}$ & Stretching of aromatic ethers, polysaccharides $(\mathrm{C}-\mathrm{H}$ stretching) \\
$<1000 \mathrm{~cm}^{-1}$ &
\end{tabular}

Table 4 Absorbance bands from the FTIR spectra in the extract made with ethyl acetate of OMW

\begin{tabular}{ll}
\hline Wavelength & Assignments \\
\hline $3300 \mathrm{~cm}^{-1}$ & $\mathrm{OH}$ (phenols, alcohols, and carboxylic groups) \\
$3065 \mathrm{~cm}^{-1}$ & $\mathrm{C}-\mathrm{H}$ stretching in aromatic structures \\
$2938 \mathrm{~cm}^{-1}$ & $\mathrm{C}-\mathrm{H}$ stretching in aliphatic structures (fatty acids, waxes, and other long-chain structures) \\
$1709 \mathrm{~cm}^{-1}$ & $\mathrm{C}=\mathrm{O}$ stretching in carboxyls, acids, and ketones \\
$1374 \mathrm{~cm}^{-1}$ & OH deformation and C-O stretching in phenolic $\mathrm{OH}, \mathrm{C}-\mathrm{H}$ deformation of $\mathrm{CH}_{2}$ and $\mathrm{CH}_{3} \mathrm{groups}^{\mathrm{COO}}$ antisym- \\
$1239 \mathrm{~cm}^{-1}$ & metric stretching \\
$1045 \mathrm{~cm}^{-1}$ & $\mathrm{C}-\mathrm{H}$ stretching and OH deformation in carboxyls, $\mathrm{C}-\mathrm{O}$ of ethers on an aromatic ring, and the N-H of amides II \\
\hline
\end{tabular}


Fig. 2 DPPH scavenging activities of OMW extract and standard antioxidant BHT and BHA

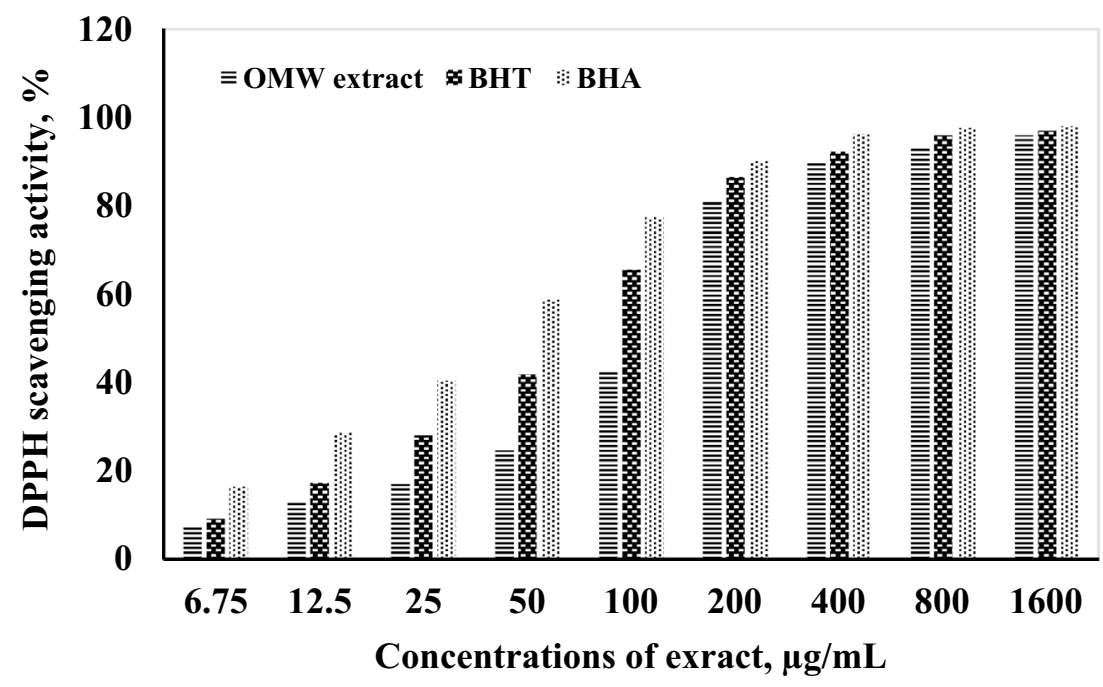

Fig. 3 Calculation of $\mathrm{IC}_{50}$ value for OMW extract

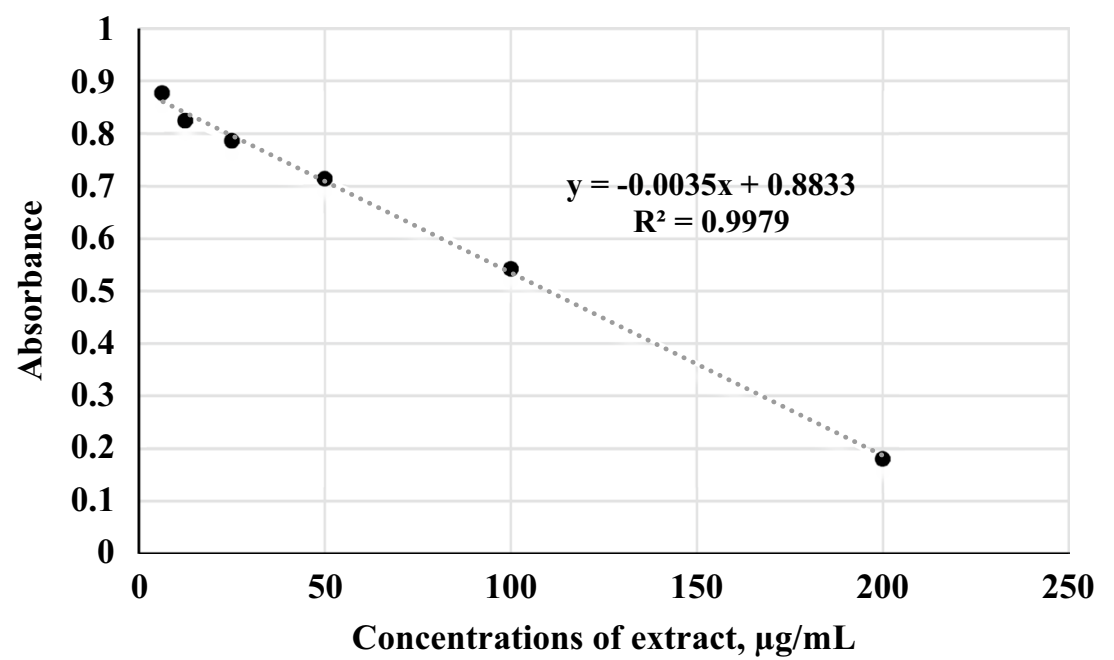

Advanced oxidation processes (AOP) involve the formation and activation of hydroxyl radicals, which are unstable and reactive species formed by an oxygen source and an energy source.

\subsection{Antioxidant activity of phenolic extracts and NMR results of extracts}

The release of OMW in large quantities creates the idea of evaluation instead of removing [2]. Therefore, the antioxidant activity of OMW was investigated. For this purpose, $50 \mathrm{~mL}$ of OWM was extracted with $3 \times 50 \mathrm{~mL}$ ethyl acetate. After the solvent was evaporated, $2.1 \mathrm{~g}$ of extract was obtained. OMW extracts were tested for antioxidant activity using a stable free radical DPPH as test $[13,16]$. The result of DPPH scavenging activity for each sample concentration was given as percentage (Fig. 2). Then, the $I C_{50}$ values were calculated for OMW extract (Fig. 3) and
Table 5 Scavenging effects $\left(\mathrm{IC}_{50} \mu \mathrm{g} / \mathrm{mL}\right.$ ) of OMW extracts on DPPH free radicals

\begin{tabular}{llll}
\hline & OMW extract & BHT & BHA \\
\hline $\mathrm{IC}_{50}(\mu \mathrm{g} / \mathrm{mL})$ & 118 & 69 & 38 \\
\hline
\end{tabular}

references. According to all of these results, the extract of OMW showed good DPPH scavenging activity (Table 5).

Antiradical activity $\mathrm{IC}_{50}(\mu \mathrm{g} / \mathrm{mL})$ was defined as the concentration of extracts necessary to decrease the initial DPPH radical concentration by $50 \%$. With this result, we showed that the OMW can be used as antioxidant instead of degradation. Lafka et al. [18] and Abbasi-El et al. [2] investigated antioxidant activity of OMW with different extraction methods, and they showed that the activity of extracts changed according to extraction solvent. While Abbasi-El et al. [2] obtained IC ${ }_{50}$ values between 123 and 
$263 \mu \mathrm{g} / \mathrm{mL}$, Azaizeh et al. [5] obtained values between 20 and $34 \mu \mathrm{g} / \mathrm{mL}$, and we obtained the value as $118 \mu \mathrm{g} / \mathrm{mL}$. These results showed that the $\mathrm{IC}_{50}$ values can be changed according to extraction methods of OMW or region where take the OMW.

Also, DPPH scavenging activity of OWM after degradation with condition in entry 7 (Table 2) was investigated. For this purpose, the OWM was extracted with $3 \times 50 \mathrm{~mL}$ ethyl acetate after degradation proses, and $0.08 \mathrm{~g}$ extract was obtained that showed only $7 \%$ antioxidant activity for $1600 \mu \mathrm{g} / \mathrm{mL}$ concentration. This result supported the successful degradation of the phenolic compounds in OWM with condition in entry 7 (Table 2). Besides the COD measurement, these results showed that we can support antioxidant activity measurement whether the OMW degradation achieved or not. In addition, we investigated the NMR spectrum of extracts before and after degradation. When these NMR spectra were compared, it was observed that all the phenolic compounds and the majority of other compounds in OWM were removed (Fig. 4).

\section{Conclusion}

Olive oil wastewater is a big environmental problem worldwide. Every year, millions of tons of toxic wastes are produced, and most of them cause serious damage to the environment. It is known that different olive wastes contain phenolic compounds at high concentrations [12, $19,24,26]$. The presence of organic pollutants was determined by FTIR measurements of the extract obtained from hexane and ethylacetate extraction of OMW. Therefore, it is necessary to either reduce the damage by oxidizing the OMW or make it usable. In this study, oxidation methods are presented for the disposal of OMW. Eight different studies were performed. High-pressure tests were limited to $3 \mathrm{~h}$, and atmospheric pressure tests were limited to $3 \mathrm{~h}$. As a result, although the time was short, the reaction with $\mathrm{H}_{2} \mathrm{O}_{2}$ at high temperature and high pressure was observed to be successful. This also shows that high-pressure and high-temperature reactions were successfully used for dephenolysis, desulfurization, and COD removal from

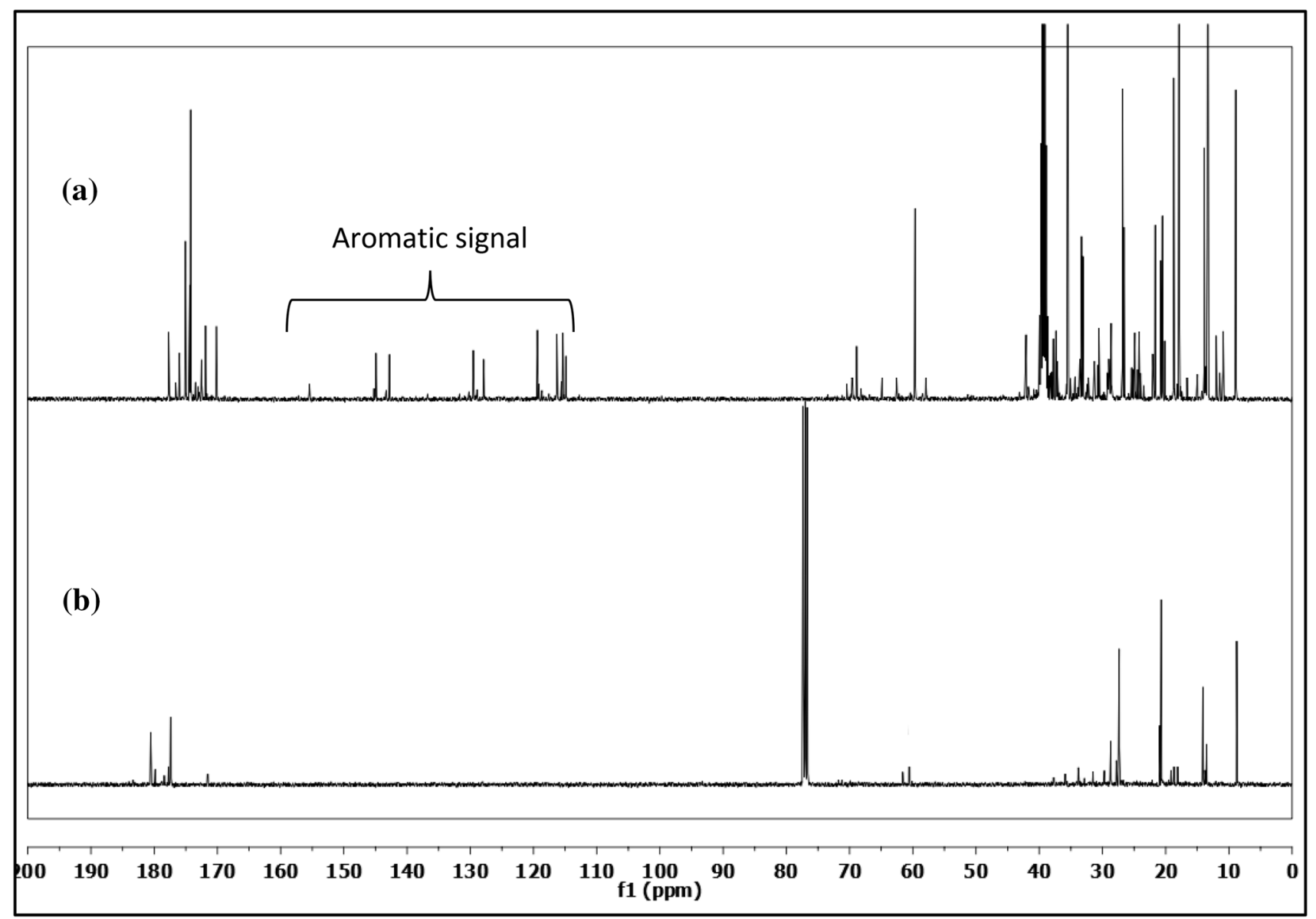

Fig. $4{ }^{13} \mathrm{C}$ NMR spectrum a extracts of OWM with EtOAC and $\mathbf{b}$ extracts of OWM with EtOAc after degradation process with condition in Table 2/entry 7 
real OMW. Oxidation reactions of OMW were carried out in seven separate systems. The high pressure and temperature oxidation with $3 \mathrm{~mL}$ of $\mathrm{H}_{2} \mathrm{O}_{2}$ was very effective for the removal of many organic pollutants from OMW. Treatment with $\mathrm{O}_{2}$ and $3 \mathrm{~mL}$ of $\mathrm{H}_{2} \mathrm{O}_{2}$ for $3 \mathrm{~h}$ caused disappearance of the majority of the phenolic compounds (91.5\%). In addition, $89.2 \%$ reduction in compounds responsible for COD was achieved. Antioxidant measurements were also performed to make OMW available. It was seen that OMW's phenolic extracts have high antioxidant potential. The results of our study show that these extracts could be used as an antioxidant source. In further studies can be investigated the content of OMW extracts in detail, and molecules responsible from antioxidant activity.

Acknowledgements This research was supported by a Grant from Mersin University (Grant Number: BAP 2015-TP2-1234).

\section{Compliance with ethical standards}

Conflict of interest The authors declare that they have no conflict of interest.

\section{References}

1. Abbasi-El A, Hafidi A, Khayet M (2011) Micellar enhanced ultrafiltration process for the treatment of olive mill wastewater. Water Res 45:4522-4530. https://doi.org/10.1016/j.watres.2011.05.044

2. Abbasi-El A, Kiai H, Hafidi A (2012) Phenolic profile and antioxidant activities of olive mill wastewater. Food Chem 132:406412. https://doi.org/10.1016/j.foodchem.2011.11.013

3. Abbasi-El A, Hafidi A, Khayet M, Garcia-Payo MC (2013) Integrated direct contact membrane distillation for olive mill wastewater treatment. Desalination 323:31-38. https://doi. org/10.1016/j.desal.2012.06.014

4. Adhoum N, Monser L (2004) Decolourization and removal of phenolic compounds from olive mill wastewater by electrocoagulation. Chem Eng Process 43:1281-1287. https://doi. org/10.1016/j.cep.2003.12.001

5. Azaizeh H, Halahlih F, Najami N, Brunner D, Faulstich M, Tafesh A (2012) Antioxidant activity of phenolic fractions in olive mill wastewater. Food Chem 134:2226-2234. https://doi. org/10.1016/j.foodchem.2012.04.035

6. Azbar N, Bayram A, Filibeli A, Muezzinoglu A, Sengul F, Ozer A (2004) A review of waste management options in olive oil production. Crit Rev Environ Sci Technol 34:209-247. https://doi. org/10.1080/10643380490279932

7. Beltran-Heredia J, Torregrosa J, Garcia J, Dominguez JR, Tierno JC (2001) Degradation of olive mill wastewater by the combination of Fenton's reagent and ozonation processes with an aerobic biological treatment. Water Sci Technol 44:103-108. https://doi. org/10.2166/wst.2001.0262

8. Beltran-Heredia J, Torregrosa J, Dominguez JR, Garcia J (2000) Treatment of black-olıve wastewaters by ozonatıon and aerobıc bıological degradatıon. Water Res 34:3515-3522. https://doi. org/10.1016/S0043-1354(00)00111-1

9. Chedeville O, Debacq M, Porte C (2009) Removal of phenolic compounds present in olive mill wastewaters by ozonation.
Desalination 249:865-869. https://doi.org/10.1016/j.desal .2009.04.014

10. El Hajjouji H, Fakharedine N, Ait Baddi G, Winterton P, Bailly JR, Revel JC, Hafidi M (2007) Treatment of olive mill wastewater by aerobic biodegradation: an analytical study using gel permeation chromatography, ultraviolet-visible and Fourier transform infrared spectroscopy. Bioresour Technol 98:35133520. https://doi.org/10.1016/j.biortech.2006.11.033

11. El Hajouji $\mathrm{H}$ et al (2008) Photochemical UV/TiO 2 treatment of olive mill wastewater (OMW). Bioresour Technol 99:72647269. https://doi.org/10.1016/j.biortech.2007.12.054

12. Fountoulakis MS, Dokianakis SN, Kornaros ME, Aggelis GG, Lyberatos G (2002) Removal of phenolics in olive mill wastewaters using the white-rot fungus Pleurotus ostreatus. Water Res 36:4735-4744. https://doi.org/10.1016/s0043 $-1354(02) 00184-7$

13. Güzel $S$ et al (2019) Wound healing properties, antimicrobial and antioxidant activities of Salvia kronenburgii Rech. f. and Salvia euphratica Montbret, Aucher \& Rech. f. var. euphratica on excision and incision wound models in diabetic rats. Biomed Pharmacother 111:1260-1276. https://doi.org/10.1016/j.bioph a.2019.01.038

14. Hafidi M, Amir S, Revel J-C (2005) Structural characterization of olive mill waster-water after aerobic digestion using elemental analysis, FTIR and 13C NMR process. Biochemistry 40:26152622. https://doi.org/10.1016/j.procbio.2004.06.062

15. Jarboui R, Sellami F, Azri C, Gharsallah N, Ammar E (2010) Olive mill wastewater evaporation management using PCA method case study of natural degradation in stabilization ponds (Sfax, Tunisia). J Hazard Mater 176:992-1005. https://doi. org/10.1016/j.jhazmat.2009.11.140

16. Kumar A, Varadaraj BG, Singla RK (2013) Synthesis and evaluation of antioxidant activity of novel 3,5-disubstituted-2-pyrazolines. Bull Fac Pharm Cairo Univ 51:167-173. https://doi. org/10.1016/j.bfopcu.2013.04.002

17. Kus NS (2012) Organic reactions in subcritical and supercritical water. Tetrahedron 68:949-958. https://doi.org/10.1016/j. tet.2011.10.070

18. Lafka TI, Lazou AE, Sinanoglou VJ, Lazos ES (2011) Phenolic and antioxidant potential of olive oil mill wastes. Food Chem 125:92-98. https://doi.org/10.1016/j.foodchem.2010.08.041

19. Lesage-Meessen $L$ et al (2001) Simple phenolic content in olive oil residues as a function of extraction systems. Food Chem 75:501-507. https://doi.org/10.1016/s0308-8146(01)00227-8

20. Monteiro D, Martins B, Fernandes C (2015) Preliminary results of olive mill wastewaters treatment by immobilized microalgae. Aperito J Cell Mol Biol 1:1-105. https://doi.org/10.14437/AJCMB $-1-105$

21. Nassar NN, Arar LA, Marei NN, Abu Ghanim MM, Dwekat MS, Sawalha SH (2014) Treatment of olive mill based wastewater by means of magnetic nanoparticles: decolourization, dephenolization and COD removal. Environ Nanotechnol Monit Manag 1-2:14-23. https://doi.org/10.1016/j.enmm.2014.09.001

22. Niaounakis M, Halvadakis CP (2006) Olive processing waste management. Pergamon, Oxford. ISBN 9780080448510

23. Ouatmane A, Dorazio V, Hafidi M, Revel JC, Senesi N (2000) Elemental and spectroscopic characterization of humic acids fractionated by gel permeation chromatography. Agronomie 20:491-504. https://doi.org/10.1051/agro:2000144

24. Peixoto F, Martins F, Amaral C, Gomes-Laranjo J, Almeida J, Palmeira CM (2008) Evaluation of olive oil mill wastewater toxicity on the mitochondrial bioenergetics after treatment with Candida oleophila. Ecotox Environ Safe 70:266-275. https://doi. org/10.1016/j.ecoenv.2007.11.003

25. Roig A, Cayuela ML, Sanchez-Monedero MA (2004) The use of elemental sulphur as organic alternative to control $\mathrm{pH}$ during 
composting of olive mill wastes. Chemosphere 57:1099-1105. https://doi.org/10.1016/j.chemosphere.2004.08.024

26. Roig A, Cayuela ML, Sanchez-Monedero MA (2006) An overview on olive mill wastes and their valorisation methods. Waste Manag 26:960-969. https://doi.org/10.1016/j.wasma n.2005.07.024

27. Smidt E, Meissl K (2007) The applicability of Fourier transform infrared (FT-IR) spectroscopy in waste management. Waste Manag 27:268-276. https://doi.org/10.1016/j.wasma n.2006.01.016

28. Tanaka K, Calanag RCR, Hisanaga T (1999) Photocatalyzed degradation of lignin on $\mathrm{TiO}_{2}$. J Mol Catal A Chem 138:287-294. https ://doi.org/10.1016/S1381-1169(98)00161-7

29. Yabalak E, Görmez Ö, Gözmen B (2017) Degradation, dephenolisation and dearomatisation of olive mill wastewater by subcritical water oxidation method using hydrogen peroxide: application of multi-response central composite design. J Serbian Chem Soc 83:489-502. https://doi.org/10.2298/JSC17 0909113Y

30. Yabalak E, Yilmaz Ö (2019) Eco-friendly approach to mineralise 2-nitroaniline using subcritical water oxidation method: use of ANN and RSM in the optimisation and modeling of the process. J Iran Chem Soc 16:117-126. https://doi.org/10.1007/s1373 8-018-1487-8

Publisher's Note Springer Nature remains neutral with regard to jurisdictional claims in published maps and institutional affiliations. 